\title{
Low temperature superplastic-like deformation and fracture behavior of nano/ultrafine-grained metastable austenitic stainless steel
}

\author{
G.S. Sun ${ }^{\mathrm{a}}$, L.X. Du ${ }^{\mathrm{a},{ }^{*},}$ J. Hu${ }^{\mathrm{a}}$, H. Xie ${ }^{\mathrm{a}}$, R.D.K. Misra ${ }^{\mathrm{b}}$
}

${ }^{\mathrm{a}}$ The State Key Laboratory of Rolling and Automation Northeastern University, Shenyang 110819, China

${ }^{\mathrm{b}}$ Laboratory for Excellence in Advanced Steel Research, Department of Metallurgical, Materials and Biomedical Engineering, University of Texas at El Paso, 500W. University Avenue, E1 Paso, TX 79968, USA.

\begin{abstract}
$\underline{\text { Abstract }}$
We describe here the low temperature superplastic-like deformation in a nano/ultrafine-grained metasable austenitic stainless steel tensile tested at a strain rate of $2.5 \times 10^{-4} \mathrm{~s}^{-1}$ and temperature of $600{ }^{\circ} \mathrm{C}$ ( 0.43 of the absolute melting point). The nano/ultrafine-grained structure was obtained via a combination of cold rolling ( $\sim 93 \%$ in reduction), followed by reversion annealing treatments at $650^{\circ} \mathrm{C}$ for $10 \mathrm{~min}, 30 \mathrm{~min}$, and $700^{\circ} \mathrm{C}$ for $2 \mathrm{~min}, 5 \mathrm{~min}$, respectively, an approach previously adopted by Misra's group (references 11-16). The reversion of martensite to austenite was dominated by diffusional mechanism. The nano/ultrafine-grained steel exhibited superplastic-like behavior with maximum elongation approaching $\sim 153 \%$ and strain rate sensitivity of $\sim 0.22$. Furthermore, tensile deformation behavior at $20^{\circ} \mathrm{C}$ and $600^{\circ} \mathrm{C}$, and the corresponding fracture characteristics are discussed. Observations of fracture surface indicated that the fracture was characterized by line-up of voids along the striations, when tensile tested at $20^{\circ} \mathrm{C}$. Whereas, the fracture surface at $600^{\circ} \mathrm{C}$ mainly consisted of uniform distribution of dimples. To further study the fracture mechanism during superplastic-like deformation, deformed structures from the longitudinal region close to the tip of the fracture surface were studied. The fracture surface of superplastic-like deformed steel was characterized by interlinkage of cavities.
\end{abstract}

Keywords: Austenitic stainless steel; Nano/ultrafine-grained structure; Reversion mechanism; Superplasticity; Fracture

Corresponding author: L.X. Du, Tel.: +86 24 83683603, Fax: +86 24 23906472, E-mail address: dulx@ ral.neu.edu.cn. 


\section{Introduction}

Superplasticity represents the ability of the material to sustain large plastic deformation prior to failure [1-3]. There is no doubt that superplastic forming will become more widespread, because it can be used to fabricate components with complex shapes and curved parts. According to previous studies on superplastic behavior, conditions that are considered necessary for superplasticity include deformation temperature near or over 0.5 melting point $\left(\mathrm{T}_{\mathrm{m}}\right)$ [4-5], deformation rate of $1 \times 10^{-5}-1 \times 10^{2} \mathrm{~s}^{-1}$ [6-7], and a stable fine-grained microstructure. It is acknowledged that grain-boundary sliding is an important deformation mechanism during superplasticity, and it is attributed to the diffusional creep and intergrannular slip. Therefore, fine-grained microstructure is preferred because the number of grain boundaries involved in sliding is high the distance for accommodation by diffusion and/or slip is small [8]. Meanwhile, finer grain size leads to smaller cavity size, and grain rotation and sliding are easier to carry out. Moreover, with reduction in grain size, the flow stress decreases, and superplastic behavior can be observed at higher strain rate and lower temperature [1-3]. Thus, superplasticity in nanocrystalline materials has attracted significant interest. In addition, high percentage of high-angle grain boundaries (HAGBs with misorientation $\geq 15^{\circ}$ ) can enhance superplastic deformation kinetics because grain-boundary sliding can occur more easily along HAGBs than LAGBs during superplastic deformation. This has been elucidated by Wang et al. in fine-grained Al-Mg-Sc alloys, and a modified superplastic constitutive equation including percentage of HAGBs as a new microstructural parameter was established [9].

In recent years, attention has been focused on fabrication of nanocrystalline materials because of their unique properties compared to the conventional coarse-grained counterpart. Additionally, grain refinement is considered as a convenient method to simultaneously improve both strength and ductility, and a number of methods have been developed to fabricate nano/ultrafine-grained (NG/UFG) structure. Severe plastic deformation (SPD) methods including equal channel angular processing (ECAP), accumulative roll-bonding (ARB) and high pressure torsion (HPT) are limited to laboratory-scale [10]. An effective approach for metastable austenitic stainless steel is advanced thermo-mechanical processing involving severe cold reduction to obtain martensite structure, followed by reversion annealing of martensite to austenite, which can be conveniently extended to large-scale processing. This approach is 
considered to be a promising process to obtain NG/UFG microstructure in industrial applications and has been recently developed by Misra's group, referred as phase reversion [11-16]. Using this approach, studies have been carried out with metastable austenitic stainless steels such as 304, 301 and 201 to obtain NG/UFG structure [11-19].

In previous studies on superplastic behavior of stainless steel, austenite-ferrite dual phase stainless steel, total elongation of $\sim 200 \%$ at a temperature greater than $770^{\circ} \mathrm{C}$ was obtained. Katoh et al. [20] observed superplastic behavior in Fe-18Cr-9Ni steel at $700^{\circ} \mathrm{C}$. Tsuchiyama [21] and Suzaki [22] also obtained superplasticity in similar steel with UFG microstructure. However, the superplasticity was achieved at elevated temperature, which was greater than $0.5 \mathrm{Tm}$. Based on the fact that grain-boundary sliding is a grain-size effect which leads to superplasticity, it is of interest to obtain superplasticity at lower temperature in NG/UFG steels. In the study described here, NG/UFG reverted austenite structure coexisted with a small fraction of retained martensite. The NG/UFG structure was obtained via severe cold-rolling at room temperature and phase-reversion annealed at $650^{\circ} \mathrm{C}$ and $700^{\circ} \mathrm{C}$ for different durations. The NG/UFG steels exhibited superplastic-like behavior when tensile tested at a strain rate of $2.5 \times 10^{-4} \mathrm{~s}^{-1}$ and temperature of $600^{\circ} \mathrm{C}(\sim 0.43 \mathrm{Tm})$. The superplasticity (maximum elongation of $\sim 300 \%$, and strain rate sensitivity value of $\sim 0.33$ ) was also obtained with tensile temperature increased to $630^{\circ} \mathrm{C}$ ( $0.45 \mathrm{Tm})$. The aspects associated with the NG/UFG structure, including the transformation of austenite to strain-induced martensite during cold rolling, reversion mechanism of strain-induced martensite to austenite during annealing treatment, and the tensile behavior, are elucidated. Furthermore, fracture of steels tensile tested at temperatures of $20^{\circ} \mathrm{C}$ and $600^{\circ} \mathrm{C}$ are also discussed.

\section{Experimental procedure}

A commercial 304 austenitic stainless steel with nominal chemical composition of Fe-0.055C-0.40Si-1.63Mn-0.015Al-0.04Nb-0.08V-8.45Ni-17.30Cr (wt.\%) was studied. Specimens of dimensions $50 \times 60 \times 120 \mathrm{~mm}$ were heated to $1200^{\circ} \mathrm{C}$ and homogenized for $2 \mathrm{~h}$, and then hot rolled via 7 passes using $\Phi 450 \mathrm{~mm}$ trial rolling mill. The thickness was reduced from $50 \mathrm{~mm}$ to $5 \mathrm{~mm}$, and the hot-rolled sheet was water quenched to ambient temperature. The start and finish rolling temperatures were $1160^{\circ} \mathrm{C}$ and $1000^{\circ} \mathrm{C}$, respectively. The hot-rolled sheet was solution-treated at $1050^{\circ} \mathrm{C}$ for $30 \mathrm{~min}$, followed by water cooling. After removing the oxide scale, the steel of $4.8 \mathrm{~mm}$ in thickness was cold 
rolled to $\sim 0.32 \mathrm{~mm}$ in thickness with $93 \%$ total reduction, and $0.3-0.5 \mathrm{~mm}$ reduction was carried out in each pass depending on the rolling resistance. To obtain different microstructure, the cold-rolled samples were annealed at $650^{\circ} \mathrm{C}$ for $10 \mathrm{~min}$ and $30 \mathrm{~min}$, and at $700^{\circ} \mathrm{C}$ for $2 \mathrm{~min}$ and $5 \mathrm{~min}$, respectively, before cooling in air after taking them out of the furnace.

Standard metallographic techniques were used to prepare specimens for microstructural examination. Microstructure along the thickness direction was characterized by Zeiss Ultra 55 scanning electron microscopy (SEM) after electrochemical-etching in 65\% nitric acid solution. Transmission electron microscopy (TEM) studies were conducted with $3 \mathrm{~mm}$ diameter thin foils, electropolished using a solution of $8 \%$ perchloric acid and alcohol at a potential of $32 \mathrm{~V}$ and $-20^{\circ} \mathrm{C}$, and examined by FEI Tecnai G2 F20 TEM at an accelerated voltage of $200 \mathrm{kV}$. Specimens for tensile test were prepared along the rolling direction with gage length of $10 \mathrm{~mm}$ and width of $5 \mathrm{~mm}$. Uniaxial tensile tests were carried out using a Shimadzu AG-X universal testing machine at different strain rates $\left(2.5 \times 10^{-4} \mathrm{~s}^{-1}\right.$ and $\left.1 \times 10^{-3} \mathrm{~s}^{-1}\right)$ and temperatures $\left(20^{\circ} \mathrm{C}, 600^{\circ} \mathrm{C}, 630^{\circ} \mathrm{C}\right.$, and $\left.650^{\circ} \mathrm{C}\right)$. Phase identification and quantitative estimate of phase volume fraction were determined by X-ray diffraction (XRD) technique, using equation (1) [23]. The $\gamma(111), \gamma(200), \gamma(220)$, and $\gamma(311)$ reflections for austenite and $\alpha^{\prime}(110), \alpha^{\prime}(200)$ and $\alpha^{\prime}(211)$ for $\alpha^{\prime}$ martensite were used to calculate volume fraction of austenite and martensite. The X-ray diffraction studies were carried out at room temperature using $\mathrm{Cu} \mathrm{K}_{\alpha}$ radiation at $50 \mathrm{kV}$ and $180 \mathrm{~mA}$. During the testing process, a $2 \theta$ range from $40^{\circ}$ to $100^{\circ}$ was step-scanned with a scanning speed of $2 \mathrm{deg} / \mathrm{min}$. Background reduction, $\mathrm{K}_{2}$ stripping and data analysis were performed using the X'pert HighScore Plus software. The specimens for XRD measurements were mechanically ground and electropolished to minimize the possible error.

$$
V_{\mathrm{i}}=\frac{1 / n \sum_{j=1}^{n} I_{i}^{j} / \boldsymbol{R}_{i}^{j}}{1 / n \sum_{j=1}^{n} I_{M}^{j} / \boldsymbol{R}_{M}^{j}+1 / n \sum_{j=1}^{n} I_{A}^{j} / \boldsymbol{R}_{A}^{j}}
$$

where $\mathrm{n}$ is the number of peaks examined, $\mathrm{R}_{M}$ and $\mathrm{R}_{\mathrm{A}}$ are the relative intensities for three hkl selected reflections of $\gamma$ and $\alpha^{\prime}$ phases, while $\mathrm{I}_{\mathrm{M}}$ and $\mathrm{I}_{\mathrm{A}}$ are the integrated intensities of the corresponding phases.

\section{Results and discussion}

\section{$3.1 \gamma \rightarrow \alpha^{\prime}$ during cold rolling at room temperature}

Representative TEM micrographs of cold-rolled specimens with $\sim 93 \%$ reduction are presented in 
Figure 1. The corresponding XRD patterns of cold-rolled specimens are presented in Figure 2. The presence of $\alpha^{\prime}(110), \alpha^{\prime}(200)$ and $\alpha^{\prime}(211)$ peaks confirmed the formation of strain-induced martensite, and the $\gamma(220)$ peak indicated the existence of retained austenite. The severe cold deformation resulted in $\sim 84.4 \%$ volume fraction of strain-induced martensite and $\sim 15.6 \%$ volume fraction of austenite. The incomplete transformation from primary austenite to strain-induced martensite is mainly due to the adiabatic heating during cold deformation. The increased deformation temperature induced by adiabatic heating can increase SFE (stacking fault energy), which can retard the transformation of strain-induced martensite [24]. Cohen and Olson [25] proposed a model suggested that the kinetics of strain-induced martensite is delayed with increase in deformation temperature. Furthermore, elevated temperature reduces the chemical driving force for martensitic transformation [26].

The microstructure mainly contained two distinct types of martensite, high volume fraction of dislocation cell-type martensite (Figure 1a) and lath-type martensite (Figure 1c). With increase in degree of cold deformation, the width of martensite lath and packet size was decreased because of break-up and destruction of lath structure, such that dislocation-cell type martensite was obtained. Thus, there was a transition of cold deformed structure from lath-type to dislocation-cell type with increase in cold deformation, which was corroborated by Misra et al. in 301LN metastable austenitic stainless steel [11]. Takaki et al. also proposed that cold rolling of martensitic steel introduces slip bands in the matrix that leads to destruction of lath martensitic structure and formation of lamellar dislocation-cell structure around slip bands [27]. The corresponding selected-area-electron-diffraction (SAED) patterns of dislocation-cell type and lath-type martensite are presented in Figure 1b and Figure 1d, respectively. The dislocation-cell type martensite exhibited a ring-like diffraction pattern, while the lath-type martensite was characterized by a spot diffraction pattern from [111] zone axis of martensite. Compared to lath-type martensite, the high density of defects in the dislocation-cell type martensite is expected to accelerate transformation kinetics, because of increased number of nucleation sites. Thus, to obtain NG/UFG austenite structure, the dislocation-cell type martensite is more effective [28-29].

\section{$3.2 \alpha^{\prime} \rightarrow \gamma$ transformation during reversion annealing}

We first describe the initial annealed microstructure, prior to discussing the superplastic-like behavior and fracture mechanism. XRD patterns of experimental samples for different conditions are 
shown in Figure 2, the individual diffracting planes are clearly marked. Typical TEM micrographs of annealed specimens are presented in Figure 3. All the annealed specimens exhibited NG/UFG austenitic structure. According to phase volume fraction data, samples annealed at $650^{\circ} \mathrm{C}$ for 10 min yielded $\sim 91.7 \%$ volume fraction of reverted austenite and $\sim 8.3 \%$ volume fraction of retained martensite. Furthermore, TEM observations confirmed that the microstructure mainly consisted of reverted austenite structure. As shown in Figure 3a, there are two types of microstructural constituents, defect-free austenite grains and dislocation cell sub-structure. The average grain size of reverted austenite was $\sim 150 \mathrm{~nm}$, consisting of a few nanocrystalline $(<100 \mathrm{~nm})$ and some ultrafine $(100 \sim 250 \mathrm{~nm})$ austenite grains. Almost all the strain-induced martensite transformed into austenite in samples annealed at $650^{\circ} \mathrm{C}$ for $30 \mathrm{~min}$, $700^{\circ} \mathrm{C}$ for $2 \mathrm{~min}$, and volume fraction of martensite was $3.9 \%$ and $3.6 \%$, respectively. As presented in Figure $3 \mathrm{~b}$, a longer annealing time of $30 \mathrm{~min}$ at $650^{\circ} \mathrm{C}$ led to more equiaxed defect-free austenite, and the mean grain size was $\sim 230 \mathrm{~nm}$. Longer annealing time resulted in slight grain coarsening, and the grain size of reverted austenite was in the range of $\sim 200-350 \mathrm{~nm}$. On annealing at $700^{\circ} \mathrm{C}$ for 2 min (Figure 3c), the austenite grain size was in the range of $\sim 150-300 \mathrm{~nm}$ with average grain size of $\sim 200 \mathrm{~nm}$. Higher annealing temperature and shorter annealing time resulted in NG/UFG defect-free austenite grains that co-existed with recovered (cell-type) sub-structure (marked by the red circle as shown in Figure 3c). When specimens were annealed at $700^{\circ} \mathrm{C}$ for $5 \mathrm{~min}$, as shown in Figure $3 \mathrm{~d}$, the sub-structure disappeared and the microstructure was fully austenite, which is attributed to higher annealing temperature and a relative longer annealing time. It can be seen in Figure $3 \mathrm{~b}$ and $3 \mathrm{~d}$ that many reverted austenite grains were equiaxed, and their high-angle grain boundaries were straight and clear.

In previous studies, two different reversion mechanisms have been proposed and discussed [13, 30-31]. They are diffusional type and shear reversion, respectively. According to Tomimura et al. [30], the critical driving force for complete martensitic shear reversion was -500 J/mol. The reversion mechanism can be determined by calculating the Gibbs free energy $\left(\Delta G^{\alpha \rightarrow \gamma}\right.$ in J/mol) change between BCC and FCC structures during $\alpha^{\prime} \rightarrow \gamma$ transformation. The following equation for the ternary Fe-Cr-Ni system reported by Kaufman et al. [32] was applied in metastable austenitic stainless steel [13, 30] to determine the dominant mechanism: 


$$
\begin{aligned}
\Delta G^{\alpha \rightarrow \gamma}= & 10^{-2} \Delta G_{F e}^{\alpha \rightarrow \gamma}(100-C r-N i)-97.5 C r+2.02 C^{2}-108.8 N i+0.52 N i^{2}-0.05 C r N i \\
& +10^{-3} T\left(73.3 C r-0.67 C r^{2}+50.2 N i-0.84 N i^{2}-1.51 C r N i\right)
\end{aligned}
$$

where $\Delta G_{F e}^{\alpha \rightarrow \gamma}$ is the free energy difference in pure iron, and $\mathrm{T}$ is the temperature in Kelvin. It is to be kept in mind that the experimental steel contained other alloying elements, thus, for a more accurate estimation, it is important to take into account the effect of other alloying elements into account. Thus, we used $\mathrm{Cr}_{\mathrm{eq}}$ and $\mathrm{Ni}_{\mathrm{eq}}$ rather than just $\mathrm{Cr}$ and $\mathrm{Ni}$ in equation (2) [14]. The $\mathrm{Cr}_{\mathrm{eq}}$ and $\mathrm{Ni}_{\mathrm{eq}}$ can be determined by:

$$
\begin{gathered}
N i_{e q}=N i+0.6 M n+20 C+4 N-0.4 S i \\
C r_{e q}=C r+0.45 M o
\end{gathered}
$$

According to our calculated results using equations (2-4), the martensite shear reversion operates above the estimated temperature of $\sim 735^{\circ} \mathrm{C}$. Thus, in our experimental steel, the diffusional reversion mechanism dominated the reversion process at the two selected annealing temperatures. In addition, the relative slow heating rate of $\sim 10^{\circ} \mathrm{C} / \mathrm{s}$ provided adequate time for nucleation and growth of reverted austenite. This is in agreement with the observations in Figure 3, where higher temperature and extended annealing time led to higher degree of reversion, which has been discussed in our previous study [17].

\subsection{Superplastic-like behavior of NG/UFG steel}

The corresponding engineering stress-engineering strain curves are shown in Figure 4. When tensile tested at room temperature $\left(20^{\circ} \mathrm{C}\right)$, the samples annealed at $650^{\circ} \mathrm{C}$ for $30 \mathrm{~min}$, exhibited ultrahigh strength (yield strength of $1225 \mathrm{MPa}$ and tensile strength of $1300 \mathrm{MPa})$, but the elongation was low ( 15\%). This decrease in plasticity can be ascribed to reduced dislocation activity, which has been documented by Shen et al. [33] in an UFG 304 stainless steel with ultrahigh strength (yield strength of $\sim 1200 \mathrm{MPa}$, elongation-to-failure of $\sim 12 \%$ ). As shown in Figure 4 (curve a), plastic instability occurred during Lüders deformation, and work hardening was not observed. In NG/UFG steel, the small grains presumably did not provide enough space for dislocation storage to accommodate plastic strains. Lack of mobile dislocations and dislocation sources within grains is associated with plastic instability [34]. Dislocations are easily trapped at grain boundaries during deformation, and the time for dislocations to move to grain boundaries is shorter than that of tensile test of UFG metals [35]. Thus, lack of dislocation density reduces dislocation pile-up, and work hardening is reduced. This is different from the observation by 
Challa et al. [16]. A NG/UFG 301 austenitic stainless steel, with average grain size of $320 \mathrm{~nm}$, showed high strain hardening ability (yield strength of $768 \mathrm{MPa}$ and elongation of $\sim 34 \%$ ). The reason associated with high strain hardening ability and good ductility in NG/UFG 301 stainless steel was attributed to be deformation twinning. Even though both the experimental steels in Challa's study and our case correspond to metastable austenitic stainless steels, the difference in chemical composition led to varying stacking fault energy (SFE). The effect of SFE on deformation twining has been studied by Ueji et al. [36] and Raabe's group [37]. The higher value of SFE because of higher alloying element content (17.30Cr, $8.45 \mathrm{Ni}$ ) in our case is considered to be responsible for different deformation behavior at room temperature. The smaller grain size in our case is another important reason. Grain size can affect the stability of austenite as well as nucleation site and the rate of martensitic transformation [16]. Another reason may include the heating rate during annealing treatment and the tensile strain rate.

When the tensile test temperature was $600^{\circ} \mathrm{C}$, as shown in Figure 4 (curves b-e), all the stress-strain plots showed gradual softening after yielding, in a manner similar to the previous study [38]. The total elongation of specimens annealed at $650^{\circ} \mathrm{C}$ for $10 \mathrm{~min}$ (curve c), $700^{\circ} \mathrm{C}$ for $2 \mathrm{~min}$ (curve d) and $650^{\circ} \mathrm{C}$ for 30 min (curve e) were 117\%, 135\%, and 153\%, respectively, suggesting superplastic-like deformation behavior. The tensile strength of specimens annealed at $650^{\circ} \mathrm{C}$ for 10 min was $382 \mathrm{MPa}$. When the annealing time was extended to $30 \mathrm{~min}$, the tensile strength was decreased to $319 \mathrm{MPa}$. From the above observations and analysis, this change can be explained by the change in grain size and decrease in volume fraction of retained martensite. Tensile strength of specimens annealed at $650^{\circ} \mathrm{C}$ for 30 min and $700^{\circ} \mathrm{C}$ for $2 \mathrm{~min}$ were almost similar because of similarity in microstructure of the both specimens, including the austenite grain size and volume fraction of retained martensite. However, the total elongation decreased from $153 \%$ in sample annealed at $650^{\circ} \mathrm{C}$ for $30 \mathrm{~min}$ to $135 \%$ in specimen annealed at $700^{\circ} \mathrm{C}$ for $2 \mathrm{~min}$. The tensile strength in samples annealed at $700^{\circ} \mathrm{C}$ for 5 min was $475 \mathrm{MPa}$ and the total elongation was $70.4 \%$.

Tensile results at different strain rates and various temperatures are summarized in Table 1. Elongation higher than $200 \%$ was obtained at strain rate of $2.5 \times 10^{-4} \mathrm{~s}^{-1}$ and temperatures of $630^{\circ} \mathrm{C}, 650^{\circ} \mathrm{C}$. When tensile tested at $630^{\circ} \mathrm{C}$, the maximum elongation in samples annealed at $650^{\circ} \mathrm{C}$ for $10 \mathrm{~min}, 30 \mathrm{~min}$ were $268 \%$ and $296 \%$, respectively. When the tensile straining temperature was increased to $650^{\circ} \mathrm{C}$, the 
maximum elongation was greater than $300 \%$. In general, a higher strain rate sensitivity of 0.3 or more and elongation of over $200 \%$ are considered to be possibly implying superplasticity in a solid crystalline material [39]. The strain rate sensitivity parameter, $m$, is defined as [40]:

$$
\mathrm{m}=\left.\frac{\partial \ln \sigma}{\partial \ln \dot{\varepsilon}}\right|_{T, \varepsilon}
$$

where $\sigma$ is the flow stress and $\dot{\varepsilon}$ is the strain rate. When tensile tested at a strain rate of $2.5 \times 10^{-4} \mathrm{~s}^{-1}$ and temperature of $600^{\circ} \mathrm{C}(\sim 0.43 \mathrm{Tm})$, the maximum elongation to fracture occurred in samples annealed at $650^{\circ} \mathrm{C}$ for $30 \mathrm{~min}$, which was $153 \%$, and the strain rate sensitivity was $\sim 0.22$. This was close to the region of superplastic deformation behavior. When tensile temperature was increased to $630^{\circ} \mathrm{C}$, the strain rate sensitivity of samples annealed at $650^{\circ} \mathrm{C}$ for $10 \mathrm{~min}$ and $30 \mathrm{~min}$ were 0.36 and 0.33 , respectively. This implied that superplasticity of NG/UFG austenitic stainless steel was achieved at strain rate of $2.5 \times 10^{-4} \mathrm{~s}^{-1}$ and tensile temperature of $630^{\circ} \mathrm{C}(\sim 0.45 \mathrm{Tm})$. As shown in Table 1 , increase in tensile strength and decrease in maximum elongation occurred with increase in strain rate.

It may also be seen in Figure 4 that stress-strain plots (c)-(e) are characterized by serrated flow, also known as Portevin-Le Chatelier (PLC) effect, which is obtained in superplastic stress-strain plots of ultrahigh-carbon microalloyed steel, aluminum alloys, and magnesium alloys [38, 41]. It is well accepted that serrations are triggered by dynamic strain aging (DSA), when the solute atoms diffuse to mobile dislocations, and are temporarily stopped by obstacles. Mobile dislocations are stopped by solutes, such that the stress increases. Increased stress enables dislocations to overcome the obstacles, and the load drops. The serrations appear in stress-strain curves when the above process occurs repeatedly [42]. A key feature of thermally activated dislocation motion is that the dislocation moves in a jerky manner because the dislocations spend majority of the time to interacting with local obstacles, such as forests of dislocations, vacancies, and solute atoms [43]. High fraction of grain boundaries in nano/ultrafine grains stabilize the microstructure, making it difficult for dislocations to separate from their cloud [44]. However, annihilation of dislocations at high-angle grain boundaries is also rapid [45], and synergism of dynamic recovery and annihilation of dislocations contribute to the disappearance of PLC effect. As shown in Figures 3 and 4, different initial microstructure resulted in different tensile results, competition between locking of dislocations by solute atoms and rearrangement of the defect structure via dynamic recovery 
and annihilation of dislocations, which led to small differences in the degree of serrated flow.

As stated before, there are abundant grain boundaries in NG/UFG steels, and grain boundary sliding is expected to dominate the deformation mechanism during high-temperature deformation. It has been previously shown that more than $50 \%$ of the total strain can be ascribed to grain boundary sliding during superplasticity [46]. Typical TEM micrographs of samples annealed at $650^{\circ} \mathrm{C}$ for 30 min tensile tested at $2.5 \times 10^{-4} \mathrm{~s}^{-1}$ and temperature of $600^{\circ} \mathrm{C}$ are shown in Figure 5. The microstructure corresponding to the region close to the fracture tip was observed. As shown in Figure 5a, many austenite grains were equiaxed and defect-free indicating that grain boundary sliding mechanism determined the kinetics of superplasticity. It is necessary for accommodation processes (grain-boundary migration, recrystallization, diffusional flow, and/or dislocation slip) to accompany grain boundary sliding [38]. In our case, the accommodation process should include grain-boundary migration because many grain boundaries were free of dislocations, as observed by Misra et al. [15]. At higher magnification, concentration of dislocation slip within grains in the vicinity of grain boundaries was observed (Figure 5b). Thus, dislocation slip must be one of the processes accommodating grain boundary sliding.

\subsection{Tensile fracture characteristics}

Figures 6 and 7 show fracture surface of specimens tensile tested at strain rate of $2.5 \times 10^{-4} \mathrm{~s}^{-1}$ and temperature of $20^{\circ} \mathrm{C}$ and $600^{\circ} \mathrm{C}$, respectively. When tensile test temperature was $20^{\circ} \mathrm{C}$, predominantly dimples were observed via SEM (Figure 6a). It is known that the number of dimples depend on the number of nucleation sites. In general, grain boundaries and triple junctions can act as preferred sites for dimple nucleation. Therefore, the appearance of smaller dimples (Figure 6a) can be ascribed to higher grain boundary density in NG/UFG steel. Another observation in Figure 6a is the presence of striations (marked by write arrows). They were almost parallel to each other. At higher magnification, line-up voids were observed along of the striation (Figure 6b), and the voids were interconnected. An identical behavior was observed by Misra et al. [47]. The striated fracture behavior was attributed to be associated with twinning-induced deformation mechanism in NG/UFG steel $[16,47]$. When the tensile test temperature was $600^{\circ} \mathrm{C}$, as presented in Figure 7, the fracture surface consisted of uniformly distributed dimples. Fracture surface of samples annealed at $650^{\circ} \mathrm{C}$ for $30 \mathrm{~min}$ (Figure $7 \mathrm{~b}$ ) mainly contained large and deep dimples, indicating good tensile ductility. This is in agreement with the observation of highest elongation 
to fracture. Fracture surface of samples annealed at $650^{\circ} \mathrm{C}$ for $10 \mathrm{~min}$ (Figure $7 \mathrm{a}$ ) and $700^{\circ} \mathrm{C}$ for $2 \mathrm{~min}$ (Figure 7c) also characterized by large number of small but deep dimples, and the elongation decreased slightly compared to samples annealed at $650^{\circ} \mathrm{C}$ for $30 \mathrm{~min}$. Large and /or deep dimples are associated with superior ductility or toughness.

To further study the tensile fracture mechanism during superplastic-like behavior, the deformed structure of the longitudinal region close to the tip of the fracture surface was studied via SEM, and is presented in Figure 8. The region examined was within $\sim 400 \mu \mathrm{m}$ away from the tip of the fracture along the longitudinal direction. After tensile deformation at $600^{\circ} \mathrm{C}$, the average grain size of specimens annealed at $650^{\circ} \mathrm{C}$ for $10 \mathrm{~min}, 30 \mathrm{~min}$ and $700^{\circ} \mathrm{C}$ for 2 min was $\sim 400-600 \mathrm{~nm}$. Compared to the initial microstructure with average grain size of 150-230 nm, as shown in Figure 3, there was small grain growth. This suggested that the reverted NG/UFG austenite was stable to avoid excessive grain growth during tensile deformation. In addition, the retained martensite after reversion annealing can also be effective for suppressing grain growth of austenite because of pinning effect [21].

Another important observation was the elongated cavities, as marked in Figures 8a-c. These cavities are believed to have nucleated along the grain boundaries. It has been previously shown that cavity nucleation is caused by stress concentration induced by grain boundary sliding [46]. As shown in Figure 8, cavities seem to be present as chains, parallel to the tensile direction. Coalescence of cavities did not result in failure until certain degree of deformation was concentrated around these cavities. Previous studies indicated that there are mainly four cavity growth mechanisms during superplastic deformation. They are stress assisted vacancy diffusion, superplastic diffusion growth, plastic deformation surrounding the cavities, and cavity interlinkage, respectively [48]. In our case, cavity growth can be attributed to interlinkage of cavities. When two adjacent cavities coalesced, a large cavity is formed. During superplastic deformation, the cavities are elongated with increase in strain, and are, aligned parallel to the tensile direction. Similar behavior has also been observed in low carbon microalloyed steel with NG/UFG structure deformed at $500^{\circ} \mathrm{C}[15]$.

\section{Conclusions}

The superplastic-like deformation behavior in NG/UFG metastable austenitic stainless steel was observed at a strain rate of $2.5 \times 10^{-4} \mathrm{~s}^{-1}$ and $600^{\circ} \mathrm{C}(\sim 0.43 \mathrm{Tm})$. The reversion mechanism of strain-induced 
martensite to austenite, tensile behavior of NG/UFG steel at $20^{\circ} \mathrm{C}$ and $600^{\circ} \mathrm{C}$, and the corresponding fracture behavior were studied. Some important results are as follows:

(1) NG/UFG microstructure was obtained by cold rolling, followed by annealing at $650^{\circ} \mathrm{C}$ for 10 $\min , 30 \mathrm{~min}, 700^{\circ} \mathrm{C}$ for $2 \mathrm{~min}$, and $700^{\circ} \mathrm{C}$ for $5 \mathrm{~min}$, respectively. The average grain size was in the range of $\sim 150-300 \mathrm{~nm}$. The diffusional reversion mechanism dominated the reversion process of strain-induced martensite to austenite.

(2) Specimens annealed at $650^{\circ} \mathrm{C}$ for $10 \mathrm{~min}, 30 \mathrm{~min}$, and $700^{\circ} \mathrm{C}$ for $2 \mathrm{~min}$ exhibited superplastic-like deformation when tensile tested at $600^{\circ} \mathrm{C}$. The corresponding elongation to fracture was $117 \%, 153 \%$, 135\%, respectively. Maximum elongations of greater than $200 \%$ with a strain rate sensitivity higher than 0.3 was obtained, when straining temperature was increased to $630^{\circ} \mathrm{C}(\sim 0.45 \mathrm{Tm})$.

(3) SEM observations of the fracture surface indicated that the fracture was characterized by line-up of voids along the striations when the tensile test temperature was $20^{\circ} \mathrm{C}$. The fracture surface at $600^{\circ} \mathrm{C}$ mainly consisted of uniformly distributed dimples. Further observations of the longitudinal region close to the tip of the fracture surface indicated that the fracture during superplastic-like deformation was controlled by interlinkage of cavities.

\section{Acknowledgments}

This work was financially supported by the Fundamental Research Funds for the Central Universities [Grant No. N150704003]; the National Natural Science Foundation of China [Grant No. 51604072]; and the National High-tech R\&D Program (863 Program) [Grant No. 2015AA03A501]. R.D.K. Misra acknowledges support from National Science Foundation (USA) through grant \#DMR 1602080.

\section{$\underline{\text { References }}$}

[1] G.D. Zhan, J.E. Garay, A.K. Mukherjee, Ultralow-temperature superplasticity in nanoceramic composites, Nano Lett. 5 (2005) 2593-2597.

[2] S. Floreen, Superplasticity in pure nickel, Scripta Metall. 1 (1967) 19-23.

[3] J. Mukhopadhyay, G. Kashner, A.K. Mukherjee, Superplasticity in boron doped Ni3Al alloy, Scripta Metall. Mater. 24 (1990) 857-862.

[4] Z.Y. Ma, F.C. Liu, R.S. Mishra, Superplastic deformation mechanism of an ultrafine-grained aluminum alloy produced by friction stir processing, Acta Mater. 58 (2010) 4693-4704. 
[5] F.C. Liu, Z.Y. Ma, Contribution of grain boundary sliding in low-temperature superplasticity of ultrafine-grained aluminum alloys, Scripta Mater. 62 (2010) 125-128.

[6] F.C. Liu, Z.Y. Ma, Achieving exceptionally high superplasticity at high strain rates in a micrograined Al-Mg-Sc alloy produced by friction stir processing, Scripta Mater. 59 (2008) $882-885$.

[7] F.C. Liu, Z.Y. Ma, Superplasticity governed by effective grain size and its distribution, Mater. Sci. Eng. A 530 (2011) 548-558.

[8] T. Furuhara, T. Maki, Grain boundary engineering for superplasticity in steels, J. Mater. Sci. 40 (2005) 919-926.

[9] K. Wang, F.C. Liu, P. Xue, D. Wang, B.L. Xiao, Z.Y. Ma, Superplastic constitutive equation including percentage of high-angle grain boundaries as a microstructural parameter, Metall. Mater. Trans A 47A (2006) 546-558.

[10] Y. Estrin, A. Vinogradov, Extreme grain refinement by severe plastic deformation: a wealth of changing science, Acta Mater. 61 (2013) 782-817.

[11] R.D.K. Misra, S. Nayak, S.A. Mali, J.S. Shah, M.C. Somani, L.P. Karjalainen, On the significance of nature of strain-induced martensite on phase-reversion-induced nanograined/ultrafine-grained austenitic stainless steel, Metall. Mater. Trans. A 41 (2010) 3-12.

[12] R.D.K. Misra, S. Nayak, S.A. Mali, J.S. Shan, M.C. Somani, L.P. Karjalainen, Microstructure and deformation behavior of phase-reversion-induced nanograined/ultrafinegrained austenitic stainless steel, Metall. Mater. Trans. A 40 (2009) 2498-2509.

[13] R.D.K. Misra, Z. Zhang, P.K.C. Venkatasurya, M.C. Somani, L.P. Karjalainen, Martensite shear phase reversion-induced nanograined/ultrafine-grained Fe-16Cr-10Ni alloy: The effect of interstitial alloying elements and degree of austenite stability on phase reversion, Mater. Sci. Eng. A 527 (2010) 7779-7792.

[14] M.C. Somani, P. Juntunen, L.P. Karjalainen, R.D.K.Misra, A. Kyröläinen, Enhancedme-chanical properties through reversion in metastable austenitic stainless steels, Metall. Mater. Trans. A 40 (2009) 729-744.

[15] R.D.K. Misra, J. Hu, I.V.S. Yashwanth, V.S.A. Challa, L.X. Du, G.S. Sun, H. Xie, Phase reverted 
transformation-induced nanograined microalloyed steel: low temperature superplasticity and fracture, Mater. Sci. Eng. A 668 (2016) 105-111.

[16] V.S.A. Challa, X.L. Wan, M.C. Somani, L.P. Karjalainen, R.D.K. Misra, Strain hardening behavior of phase reversion-induced nanograined/ultrafine-grained(NG/UFG) austenitic stainless steel and relationship with grain size and deformation mechanism, Mater. Sci. Eng. A 613 (2014) 60-70.

[17] G.S. Sun, L.X. Du, J. Hu, H. Xie, H.Y. Wu, R.D.K. Misra, Ultrahigh strength nano/ultrafine-grained 304 stainless steel through three-stage cold rolling and annealing treatment, Mater. Charact. 110 (2015) 228-235.

[18] B. Ravi Kumar, S. Sharma, B.P. Kashyap, N. Prabhu, Ultrafine grained microstructure tailoring in austenitic stainless steel for enhanced plasticity, Mater. Des. 68 (2015) 63-71.

[19] P. Haušild, V. Davydov, J. Drahokoupil, M. Landa, P. Pilvin, Characterization of strain-induced martensitic transformation in a metastable austenitic stainless steel. Mater. Des. 31 (2010) 1821-1827.

[20] M. Katoh, Y. Torisaka, Thermo-mechanical treatment with multi-direction upsetting for improvement of superplasticity in SUS 304, Tetsu-to-Hagane 89 (2003) 1038-1043.

[21] T. Tsuchiyama, Y. Nakamura, H. Hidaka, S. Takaki, Effect of initial microstructure on superplasticity in ultrafine grained 18Cr-9Ni stainless steel, Mater. Trans. 45 (2004) 2259-2263.

[22] T. Suzaki, S. Takaki: Proc. PRICM3, ed. by M.A. Imam, R. DeNale, S. Hanada, Z. Zhong and D.N. Lee, Honolulu, (TMS, 1998) pp.1825-1830.

[23] A.K. De, D.C. Murdock, M.C. Mataya, J.G. Speer, D.K. Matlock, Quantitative measurement of deformation-induced martensite in 304 stainless steel by X-ray diffraction, Scripta Mater. 50 (2004) 1445-1449.

[24] S. Curtze, V.T. Kuokkala, Dependence of tensile deformation behavior of TWIP steels on stacking fault energy, temperature and strain rate, Acta Mater. 58 (2010) 5129-5141.

[25] G.B. Olson, M. Cohen, Kinetics of nucleation strain-induced martensitic, Metall. Trans. A 6A (1975) 791-795.

[26] Y.S. Jung, Y.K. Lee, D.K. Matlock, M.C. Mataya, Effect of grain size on strain-induced martensitic transformation start temperature in an ultrafine grained metastable austenitic steel, Met. Mater. Int. 
17 (2011) 553-556.

[27] S. Takaki, S. Iizuka, K. Tomimura, Y. Tokunaga, Influence of cold working on recovery and recrystallization of lath martensite in 0.2\%C steel, Mater. Trans. JIM 33 (1992) 577-584.

[28] E. Ma, Instabilities and ductility of nanocrystalline and ultrafine-grained metals, Scripta Mater. 49 (2003) 663-668.

[29] C.C. Koch, Optimization of strength and ductility in nanocrystalline and ultrafine grained metals, Scripta Mater. 49 (2003) 657-662.

[30] K. Tomimura, S. Takaki, Y. Tokunaga, Reversion mechanism from deformation induced martensite to austenite in metastable austenitic stainless steels, ISIJ Int. 31 (1991) 1431-1437.

[31] S. Takaki, K. Tomimura, S. Ueda, Effect of pre-cold-working on diffusional reversion of deformation induced martensite in metastable austenictic stainless steel, ISIJ Int. 34 (1994) 522-527.

[32] L. Kaufman, E.V. Clougherty, R.J. Weiss, The lattice stability of metals-III. Iron, Acta Metall. 11 (1963) 303-335.

[33] Y.F. Shen, X.M. Zhao, X. Sun, Y.D. Wang, L. Zuo, Ultrahigh strength of ultrafine grained austenitic stainless steel induced by accumulative rolling and annealing, Scripta Mater. 2014, In Press.

[34] Y.U. Heo, D.W. Suh, H.C. Lee, Fabrication of an ultrafine-grained structure by a compositional pinning technique, Acta Mater. 77 (2014) 236-247.

[35] K.T. Park, Y.S. Kim, J.G. Lee, D.H. Shin, Termal stability and mechanical properties of ultrafine grained low carbon steel, Mater. Sci. Eng. A 293 (2000) 165-172.

[36] R. Ueji, N. Tsuchida, D. Terada, N. Tsuji, Y. Tanaka, A. Takemura, K. Kunishige, Tensile properties and twinning behavior of high manganese austenitic steel with fine-grained structure, Scripta Mater. 59 (2008) 963-966.

[37] I. Gutierrez-Urrutia, S. Zaefferer, D. Raabe, The effect of grain size and grain orientation on deformation twinning in a Fe-22wt.\% Mn-0.6 wt.\% C TWIP steel, Mater. Sci. Eng. A 527 (2010) 3552-3560.

[38] J. Hu, L.X. Du, G.S. Sun, H. Xie, R.D.K. Misra, Low temperature superplasticity and thermal stability of a nanstructured low-carbon microalloyed steel, Sci. Rep.-Nat. 5 (2015) 18656. 
[39] R.H. Bricknell, J.W. Edington, Superplasticity in the commercial Al-Zn-Mg alloy BA 708, Metall. Trans. A 7 (1976) 153-155.

[40] H. Conrad, in: V.F. Zackey (Ed.), High-Strength Materials, Wiley, New York, NY, 1964.

[41] H. Zhang, B. Bai, D. Raabe, Superplastic martensitic Mn-Si-Cr-C steel with $900 \%$ elongation, Acta Mater. 59 (2011) 5787-5802.

[42] A.K. Gupta, S.K. Singh, S. Reddy, G. Hariharan, Prediction of flow stress in dynamic strain aging regime of austeniti stainless steel 316 using artificial neural network, Mater. Des. 35 (2012) 589-595.

[43] Y.F. Shen, P.J. Wang, Y.D. Liu, R.D.K. Misra, L. Zuo, Activated dynamic strain aging of a TRIP590 steel at $300^{\circ} \mathrm{C}$ and low strain rate and relationship to structure, Mater. Sci. Eng. A 645 (2015) 333-338.

[44] W. Blum, Y.J. Li, F. Breutinger, Deformation kinetics of coarse-grained and ultrafine-grained commercially pure Ti, Mater. Sci. Eng. A 462 (2007) 275-278.

[45] Y.J. Li, X.H. Zeng, W. Blum, Transition from strengthening to softening by grain boundaries in ultrafine-grained Cu, Acta Mater. 52 (2004) 5009-5018.

[46] X.G. Jiang, J.C. Earthman, F.A. Mohamed, Cavitation and cavity-induced fracture during superplastic deformation, J. Mater. Sci. 29 (1994) 5499-5514.

[47] R.D.K. Misra, X.L. Wan, V.S.A. Challa, M.C. Somani, L.E. Murr, Relationship of grain size and deformation mechanism to the fracture behavior in high strength-high ductility nanostructured austenitic stainless steel, Mater. Sci. Eng. A 626 (2015) 41-50.

[48]R.C. Gifkins, Grain-boundary sliding and its accommodation during creep and superplasticity, Mater. Trans. A 7A (1976) 1225-1232. 


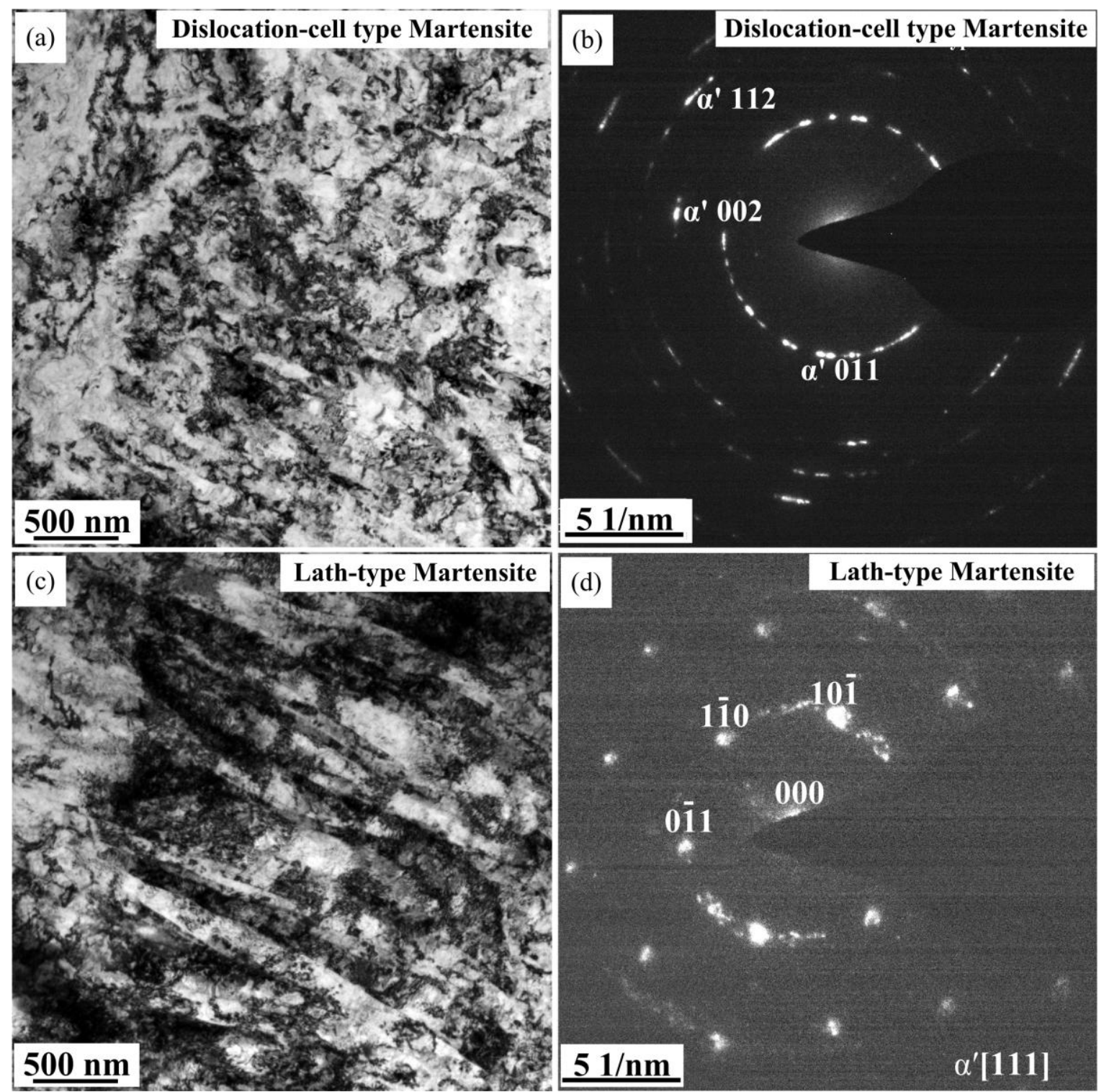

Figure 1. TEM micrographs illustrating two distinct types of strain-induced martensite in cold-rolled samples with $\sim 93 \%$ reduction. (a) dislocation-cell type martensite, (b) the corresponding SAED of dislocation-cell type martensite, (c) lath-type martensite, (d) the corresponding SAED of lath-type martensite. 


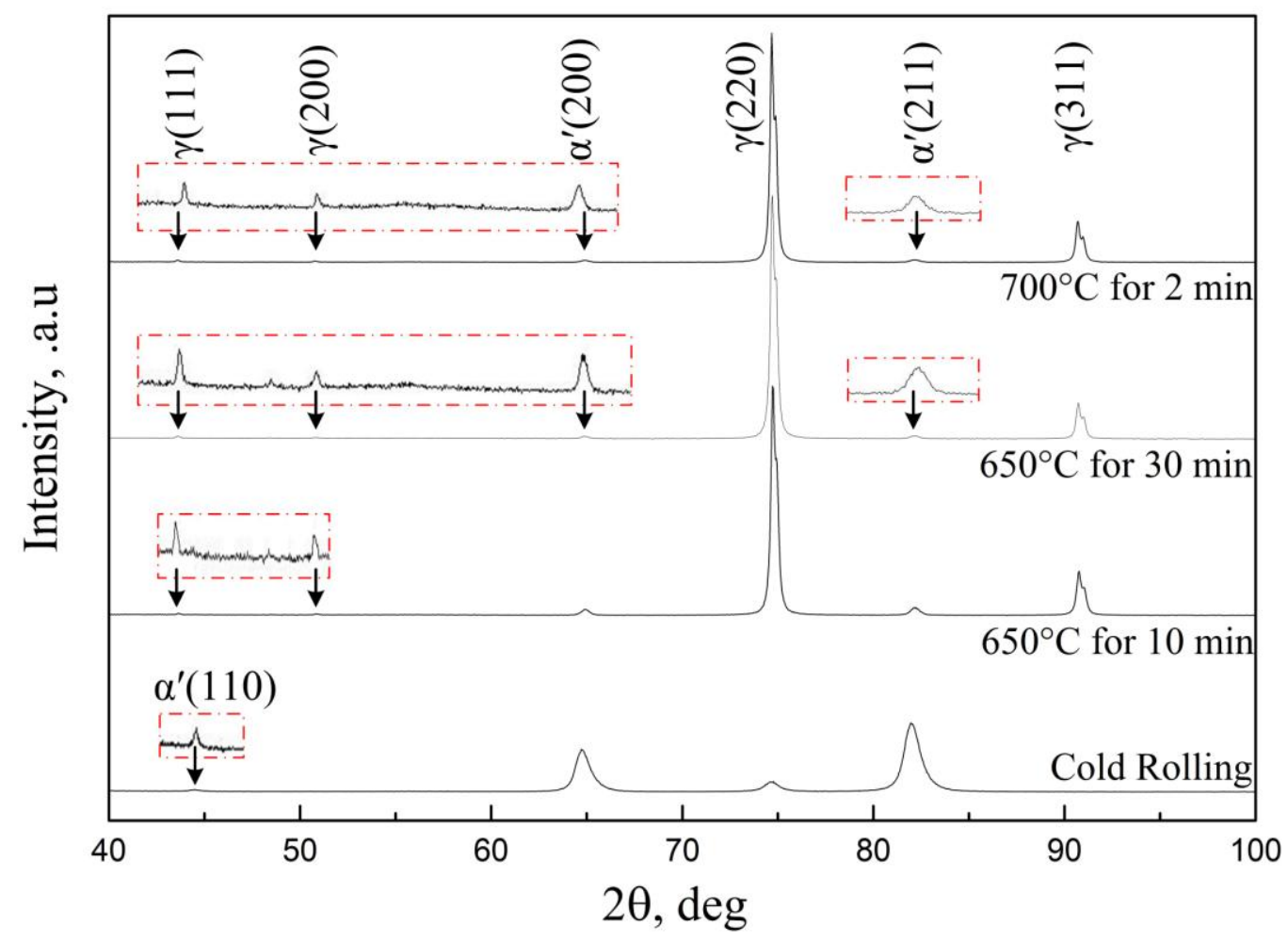

Figure 2. XRD patterns of cold-rolled sample along with those annealed at different temperatures and time. 

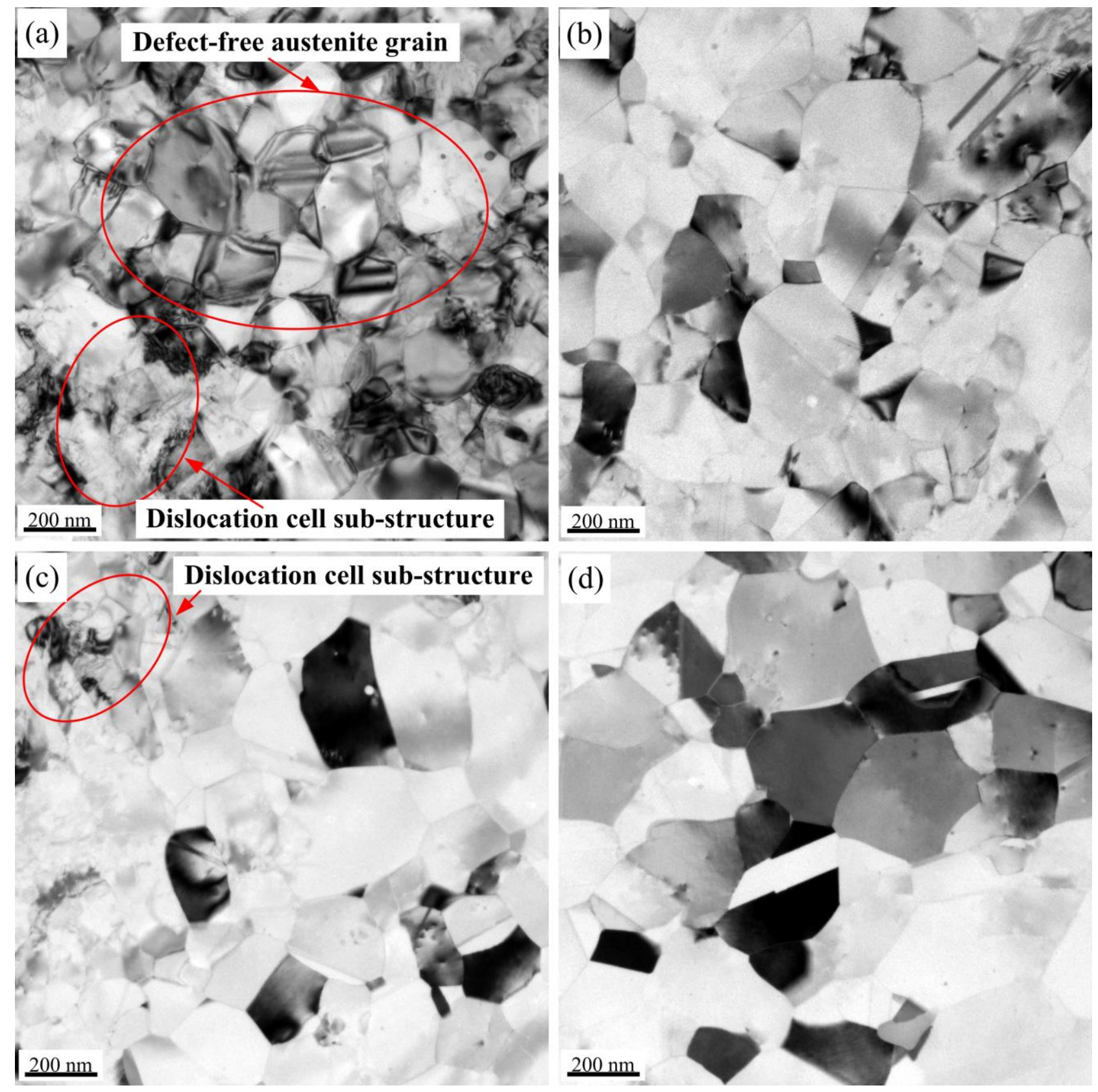

Figure 3. Typical TEM micrographs of cold-rolled specimens annealed at different temperatures and times. (a) $650^{\circ} \mathrm{C}$ for $10 \mathrm{~min}$, (b) $650^{\circ} \mathrm{C}$ for $30 \mathrm{~min}$, (c) $700^{\circ} \mathrm{C}$ for $2 \mathrm{~min}$, (d) $700^{\circ} \mathrm{C}$ for $5 \mathrm{~min}$. 


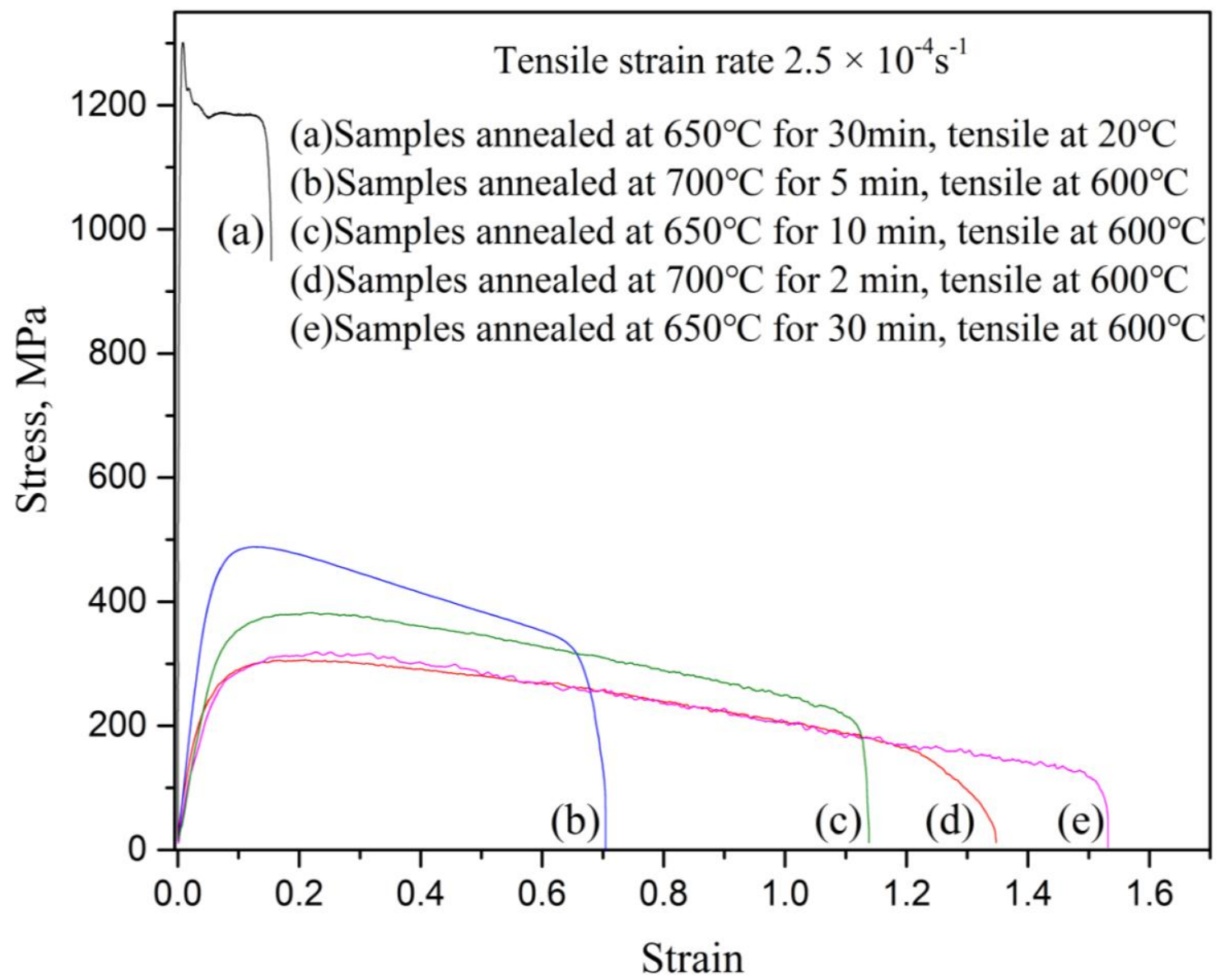

Figure 4. Tensile stress-strain plots of samples under different processing conditions. (a) samples annealed at $650^{\circ} \mathrm{C}$ for $30 \mathrm{~min}$ and strained at $2.5 \times 10^{-4} \mathrm{~s}^{-1}$ and $20^{\circ} \mathrm{C}$, (b) samples annealed at $700^{\circ} \mathrm{C}$ for 5 min and strained at $2.5 \times 10^{-4} \mathrm{~s}^{-1}$ and $600^{\circ} \mathrm{C}$, (c) samples annealed at $650^{\circ} \mathrm{C}$ for $10 \mathrm{~min}$ and strained at $2.5 \times 10^{-4} \mathrm{~s}^{-1}$ and $600^{\circ} \mathrm{C}$, (d) samples annealed at $700^{\circ} \mathrm{C}$ for $2 \mathrm{~min}$ and strained at $2.5 \times 10^{-4} \mathrm{~s}^{-1}$ and $600^{\circ} \mathrm{C}$, (e) samples annealed at $650^{\circ} \mathrm{C}$ for $30 \mathrm{~min}$ and strained at $2.5 \times 10^{-4} \mathrm{~s}^{-1}$ and $600^{\circ} \mathrm{C}$. 


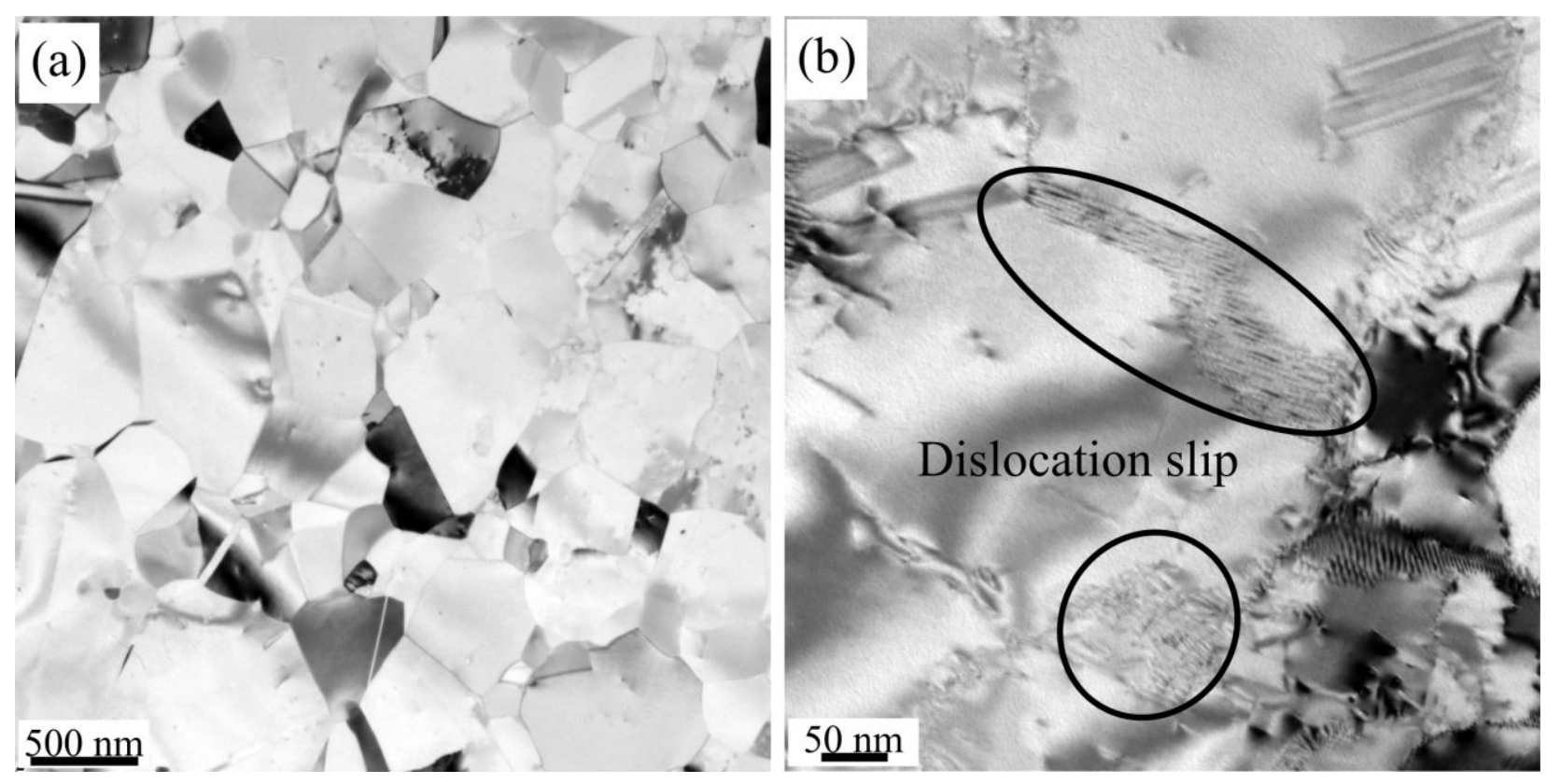

Figure 5. TEM micrographs from a region close to the tip of the fracture surface of samples annealed at $650^{\circ} \mathrm{C}$ for $30 \mathrm{~min}$ (strain rate of $2.5 \times 10^{-4} \mathrm{~s}^{-1}$ and straining temperature of $600^{\circ} \mathrm{C}$ ). (a) equiaxed defect-free austenite grain indicating grain boundary sliding, (b) dislocation slip in the vicinity of grain boundaries (indicated by circles). 

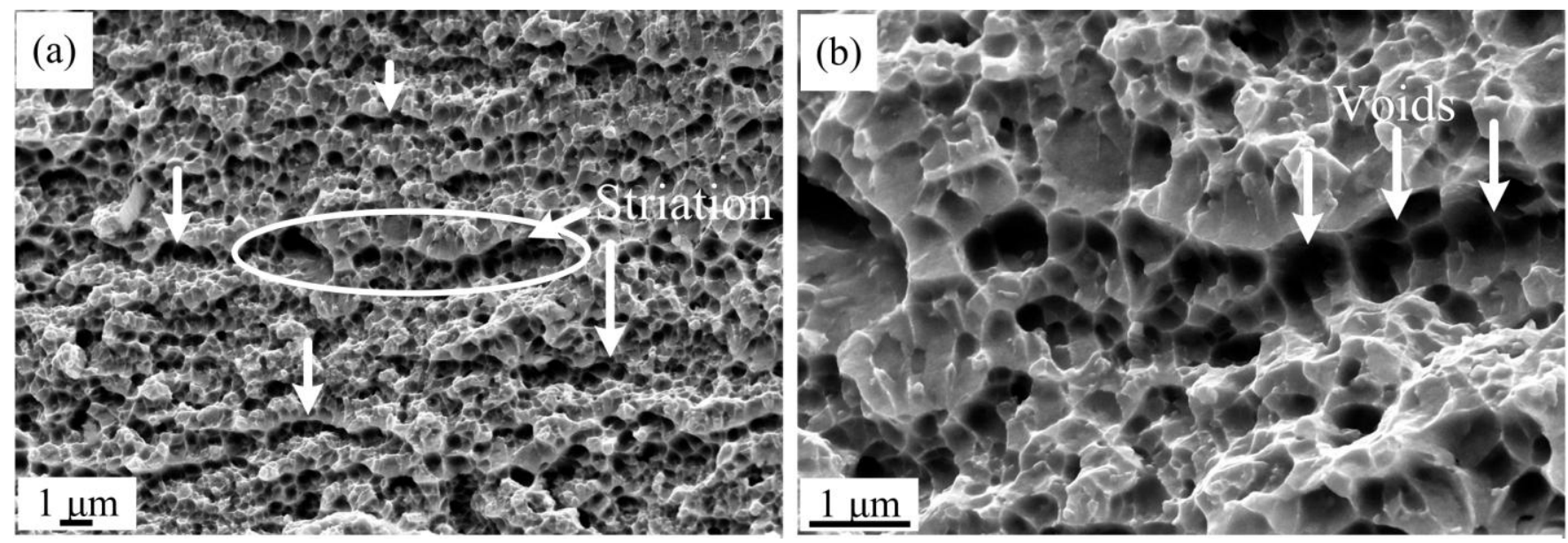

Figure 6. SEM images showing fracture surface of sample annealed at $650^{\circ} \mathrm{C}$ for $30 \mathrm{~min}$ and tensile tested at $2.5 \times 10^{-4} \mathrm{~s}^{-1}$ and $20^{\circ} \mathrm{C}$. (a) low magnification SEM image of fracture surface, (b) higher magnification SEM image of area marked by write ellipse in (a). 

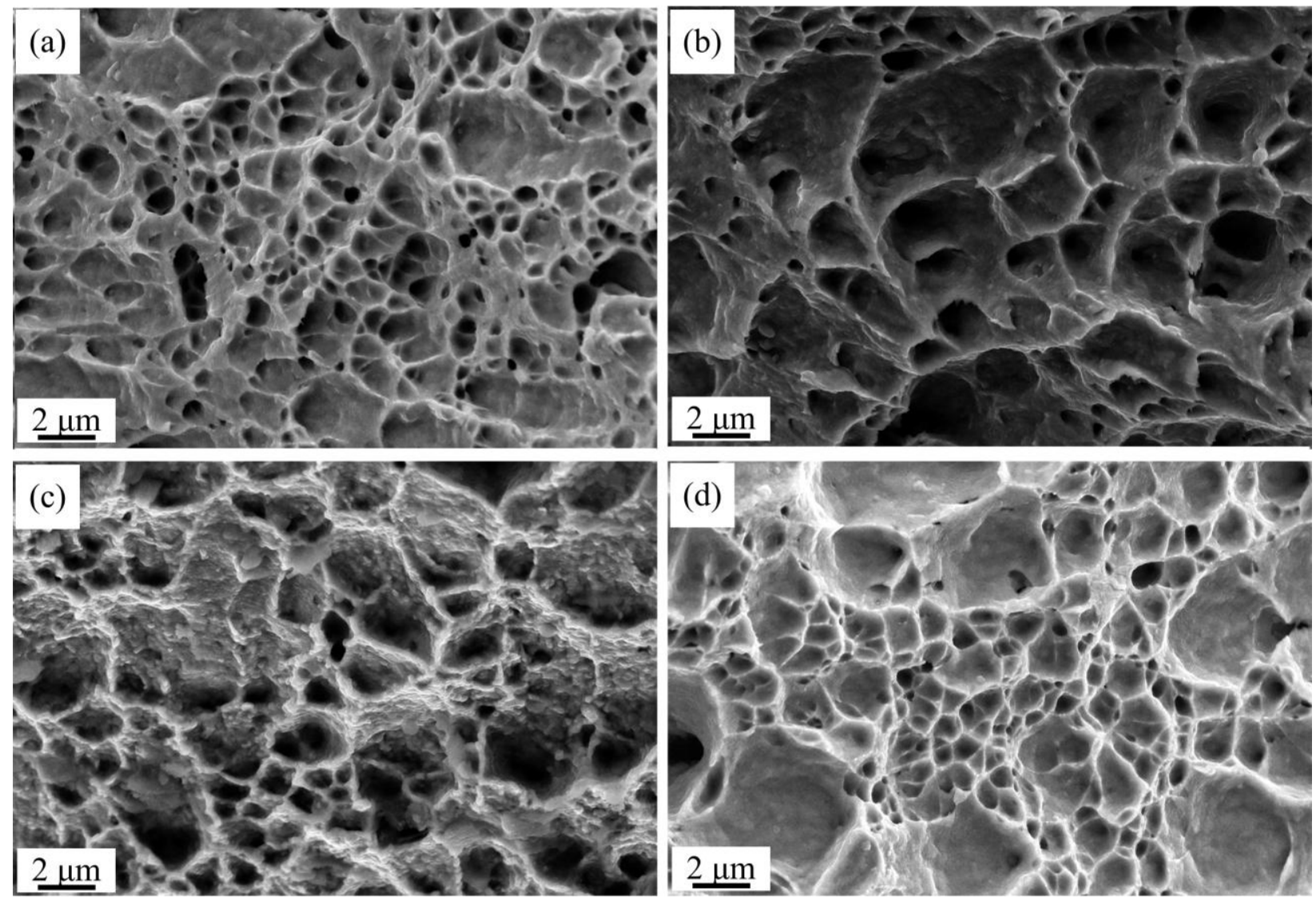

Figure 7. Fracture surface morphology of samples annealed at different parameters and tensile tested at $2.5 \times 10^{-4} \mathrm{~s}^{-1}$ and $600^{\circ} \mathrm{C}$. (a) $650^{\circ} \mathrm{C}$ for $10 \mathrm{~min}$, (b) $650^{\circ} \mathrm{C}$ for $30 \mathrm{~min}$, (c) $700^{\circ} \mathrm{C}$ for $2 \mathrm{~min}$, (d) $700^{\circ} \mathrm{C}$ for 5 $\min$. 


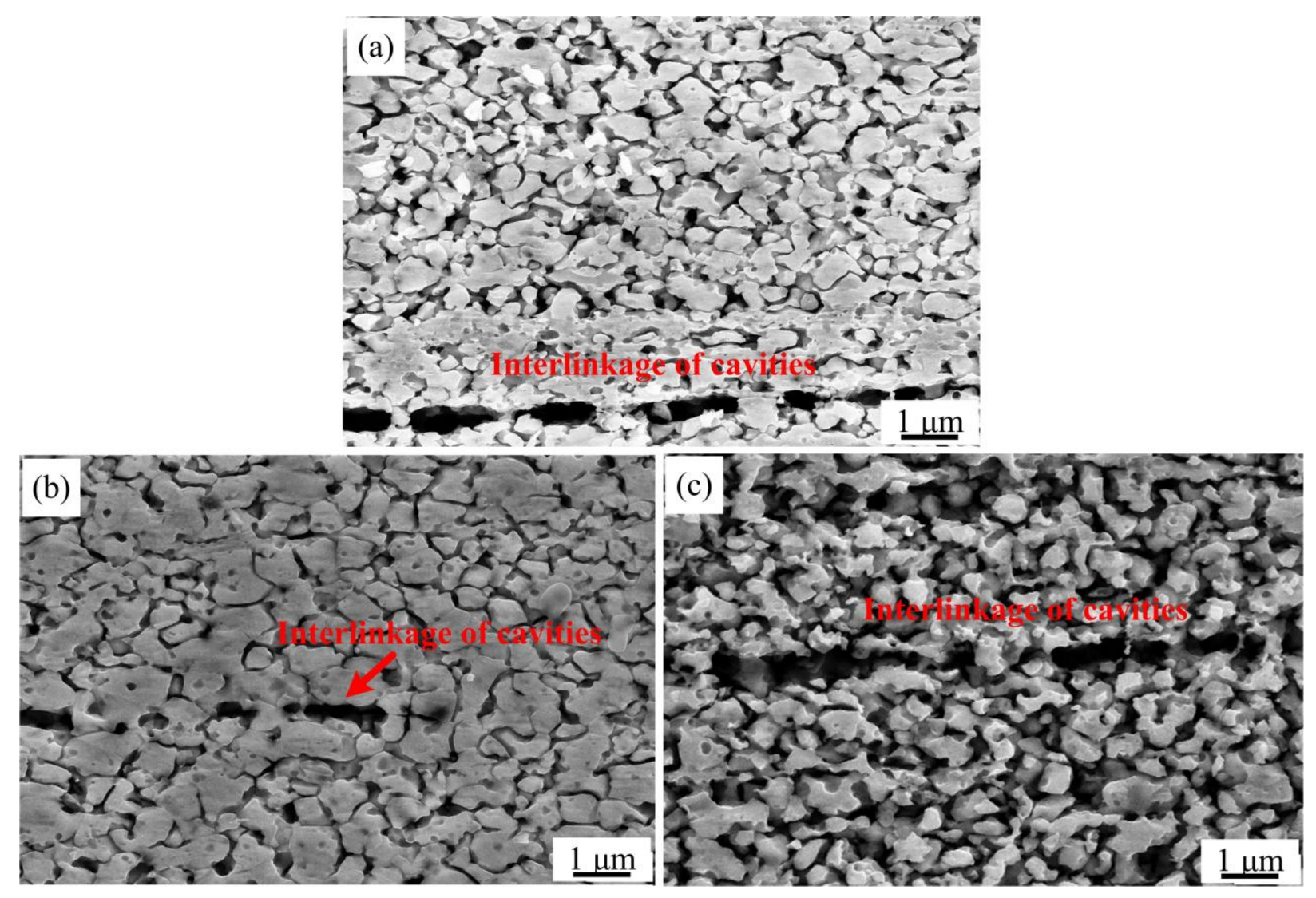

Figure 8. SEM micrographs of longitudinal region close to the tip of tensile fracture surface of specimens annealed at different temperatures and time and then tensile tested at $2.5 \times 10^{-4} \mathrm{~s}^{-1}$ and $600^{\circ} \mathrm{C}$. Note the interlinkage of cavities. (a) $650^{\circ} \mathrm{C}$ for $10 \mathrm{~min}$, (b) $650^{\circ} \mathrm{C}$ for $30 \mathrm{~min}$, (c) $700^{\circ} \mathrm{C}$ for $2 \mathrm{~min}$. 
Table 1. A summary of tensile properties of NG/UFG austenitic stainless steel tested at different strain rates and temperatures.

\begin{tabular}{ccccc}
\hline Processing condition & $\begin{array}{c}\text { Straining } \\
\text { temperature, }{ }^{\circ} \mathrm{C}\end{array}$ & Strain rate, $\mathrm{s}^{-1}$ & $\begin{array}{c}\text { Tensile strength, } \\
\text { MPa }\end{array}$ & $\begin{array}{c}\text { Elongation to } \\
\text { fracture, } \%\end{array}$ \\
\hline $650^{\circ} \mathrm{C}$ for $30 \mathrm{~min}$ & 20 & $2.5 \times 10^{-4}$ & 1300 & 15 \\
$700^{\circ} \mathrm{C}$ for $2 \mathrm{~min}$ & 600 & $2.5 \times 10^{-4}$ & 305 & 135 \\
$700^{\circ} \mathrm{C}$ for $5 \mathrm{~min}$ & 600 & $2.5 \times 10^{-4}$ & 475 & 70 \\
$650^{\circ} \mathrm{C}$ for $10 \mathrm{~min}$ & 600 & $2.5 \times 10^{-4}$ & 382 & 117 \\
& 630 & $2.5 \times 10^{-4}$ & 277 & 268 \\
$650^{\circ} \mathrm{C}$ for $30 \mathrm{~min}$ & 630 & $1 \times 10^{-3}$ & 359 & 187 \\
& 600 & $2.5 \times 10^{-4}$ & 319 & 153 \\
& 600 & $1 \times 10^{-3}$ & 515 & 112 \\
& 630 & $2.5 \times 10^{-4}$ & 269 & 296 \\
& 630 & $1 \times 10^{-3}$ & 386 & 161 \\
& 650 & $2.5 \times 10^{-4}$ & 224 & $>300$ \\
\hline
\end{tabular}




\section{Superplastic-like behavior of nano/ultrafine-grained austenitic stainless}

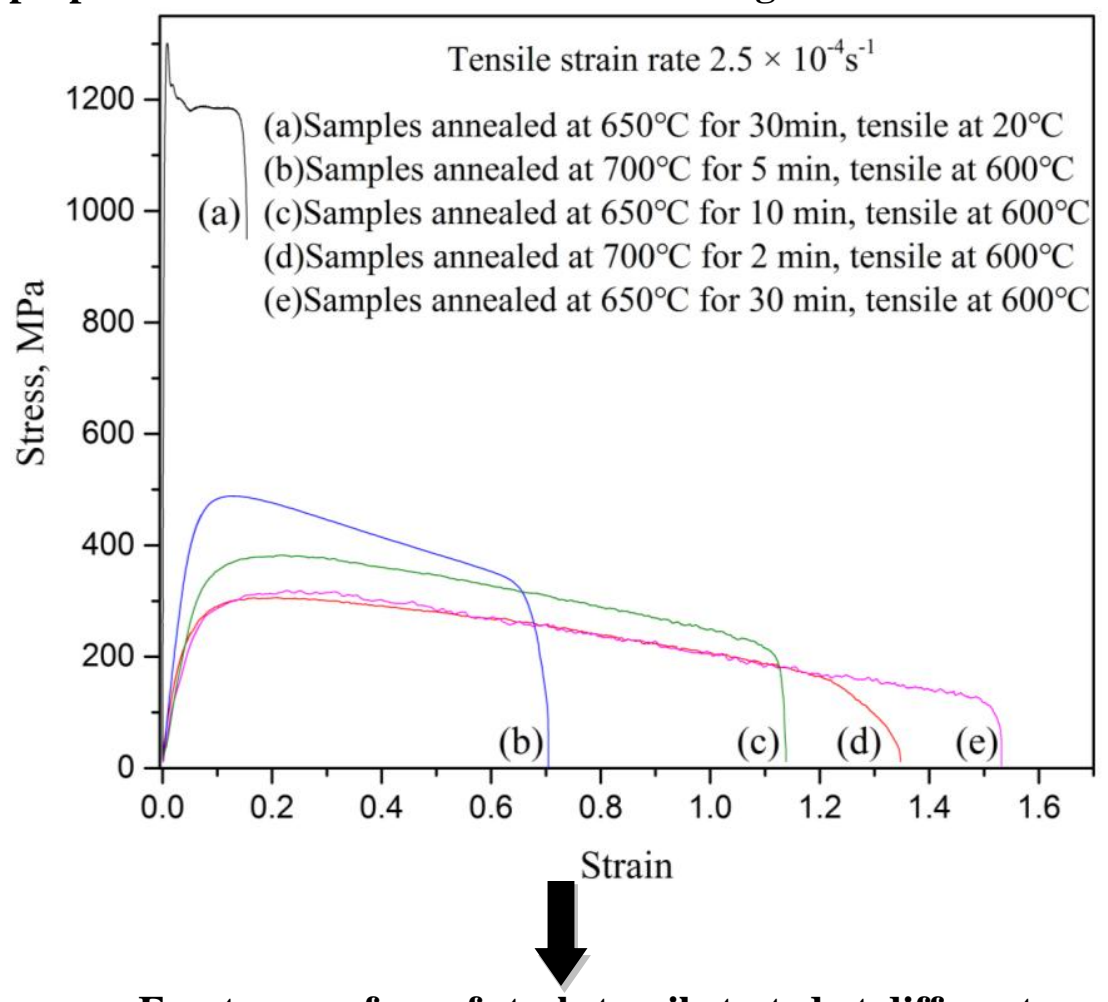

Fracture surface of steels tensile tested at different

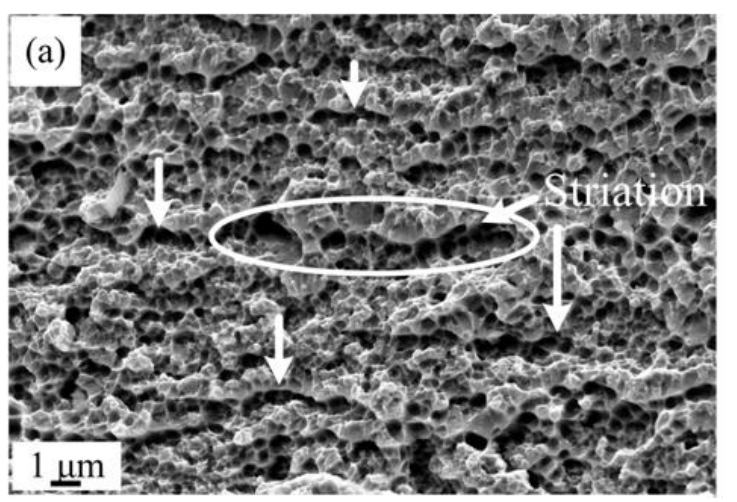

$20^{\circ} \mathrm{C}$ (curve a)

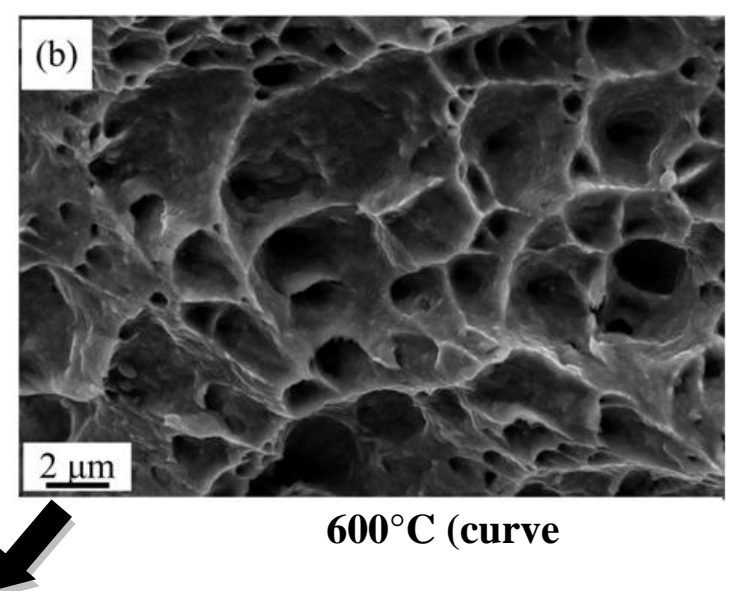

Further study on fracture mechanism during superplastic-like

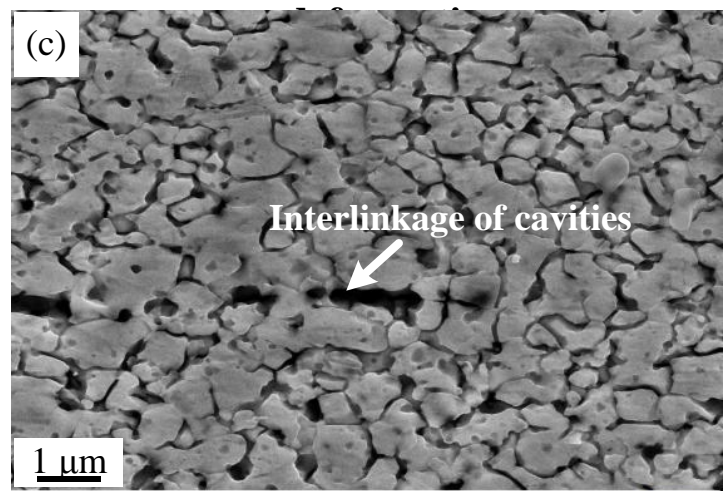

Longitudinal region close to the tip of the fracture surface

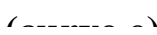

